\title{
Tareas Pendientes: Los Deberes Humanos
}

Pending Tasks: Human Duties

\section{Dr. Emilio Germán Ardiani Alvariza, Mgtr.}

Profesor de Derecho Constitucional y Ética Profesional UCEL Argentina

Artículo Original (Investigación)

RFJ, No. 3, 2018, pp. 159-197, ISSN 2588-0837

RESUMEN: este ensayo intentará realizar una aproximación a los deberes humanos a partir de la dificultad en su conceptualización, luego será necesario realizar una mirada histórica en la que se analizarán los cambios en el paradigma del Derecho y los diferentes documentos internacionales sobre la materia; este recorrido nos permitirá a su vez la posibilidad de determinar ciertas causas que han llevado a su invisibilidad, para finalmente proponer un concepto y características de los deberes humanos.

PALABRAS CLAVES: derechos humanos, deberes humanos, razón, contractualismo, derecho positivo.

ABSTRACT: this essay will try to make an approximation to the human duties from the difficulty in its conceptualization, then it will be necessary to make a historical look in which will analyze the changes in paradigm of the law and the different international documents on the subject; This route will allow us in turn the possibility of determining certain causes that have led to their invisibility, to finally propose a concept and characteristics of human duties.

KEY WORDS: human duties, human rights, reason, contractualism, positive law. 


\section{INTRODUCCIÓN}

La segunda Guerra Mundial significó para la humanidad una bisagra nunca vista en cuanto a lo que el hombre hace al hombre. ${ }^{84} \mathrm{~A}$ su término el horror develado produjo un profundo análisis acerca de las violaciones flagrantes a la dignidad del hombre que tuvo repercusiones múltiples, incluyendo la elaboración de la emblemática Declaración Universal de los Derechos Humanos de 1948 y el consecuente desarrollo de un sistema protectorio de derechos considerados fundamentales; tales derechos encuentran en la Revolución Francesa un punto de inflexión clave en su desarrollo.

La reconocida elaboración metodológica que distingue en el desarrollo de los derechos humanos en distintas generaciones ${ }^{85}$ ha puesto en consideración libertades negativas y positivas, reclamando inicialmente el derecho a la no interferencia en la primera generación, para reconocer en las siguientes generaciones acciones positivas a las que se tiene derecho.

Lo cierto es que afianzada ya una tercera generación de derechos de la solidaridad y en discusión una cuarta que involucra a la sociedad tecnológica, pese a la expansión ${ }^{86}$ de sus análisis, las violaciones de los derechos humanos no han dejado de ser una ofensa a la humanidad.

En 1998 el portugués José Saramago recibió el Premio Nobel de Literatura y en el discurso que ofreció durante el brindis correspondiente a la cena celebrada en su honor sorprendió a todos con un contundente reclamo: "Tomemos entonces, nosotros ciudadanos comunes, la palabra. Con la misma vehemencia con que reivindicamos los derechos, reivindiquemos también el deber de nuestros deberes. Tal vez así el mundo pueda ser un poco mejor."

84 Revault D'Allones (2010). 16.

85 La elaboración de la "tesis generacional" de los derechos humanos de Karel Vašák en los 70 s tiene valor como herramienta pedagógica aunque su caracterización no está exenta de críticas. De todos modos puede funcionar como recurso pedagógico a fin de mostrar una evolución en el desarrollo de los contenidos de los derechos humanos.

86 Expansión de derechos que es críticamente analizada por su desmesurada amplitud, que lleva a ver todo desde una óptica de los derechos humanos o fundamentales, y si todo pertenece a esta categoría su produce una licuación de su relevancia. Volveré sobre el tema más adelante. 
Un Saramago brillante ponía en relieve la cuestión capital de los deberes humanos, deberes que no han tenido la consideración suficiente y cuya recuperación no solo es un reclamo moral y jurídico, es parte de una explicación sobre por qué no hemos logrado evitar aquello que el hombre hace al hombre.

El trabajo aspira a presentar los deberes humanos como contenido clave de la agenda inmediata a desarrollar en materia de derechos humanos. Para ello se realizará un recorrido histórico que permita apreciar consideración filosófica, política y jurídica, y buscar explicaciones para su actual invisibilidad. A continuación se esbozará una caracterización de los "deberes" para luego realizar una aproximación a la idea de deberes humanos.

\section{UN RECORRIDO HISTÓRICO}

Derecho, moral y religión encuentran un común inicio en la antigüedad, para luego ir delineando sus ámbitos. Veamos algunos fragmentos de pensamiento antiguo.

La obra "Antígona" de Sófocles suele ser el ejemplo de esbozo de un derecho natural anterior y eterno con prevalencia por sobre la ley positiva. Lo interesante es que Antígona siente por sobre toda consideración el deber de realizar los ritos funerarios a su hermano insepulto. "Yo, por mi parte, enterraré a Polinice. Será hermoso para mí morir cumpliendo ese deber. Así reposaré junto a él, amante hermana con el amado hermano; rebelde y santa por cumplir con todos mis deberes piadosos; que más cuenta me tiene dar gusto a los que están abajo, que a los que están aquí arriba, pues para siempre tengo que descansar bajo tierra. Tú, si te parece, desprecia lo que para los dioses es lo más sagrado" ${ }^{77}$

Es el cumplimiento del deber el motivo de orgullo y fundamento del sacrificio de Leónidas y sus 300 espartanos, tal como declara la tradición histórica que atribuye al poeta Simónides: "Caminante, ve a Esparta y dile a sus ciudadanos que aquí yacemos por obedecer sus leyes".

En el libro 9, capítulo 2 de ética a Nicómaco, Aristóteles analiza el deber y sus límites; se puede advertirse claramente su posición en cuanto a que el deber es actuar con justicia devolviendo o dando a

87 Sofocles (2001). 5. 
cada uno lo que corresponde en el marco de las distintas posibles acciones que puedan realizarse en una situación. El deber es en medio para alcanzar la virtud y su importancia está en el contenido, lo cual define una concepción del deber que será contrapuesta en la modernidad al formalismo de Kant, para quien lo importante es cumplir el deber por el deber en sí mismo. La idea del Derecho como justicia es central, a tal punto que los romanos llamarán al Derecho "ius".

El hombre, ser social por naturaleza, encuentra su realización solo en sociedad y por tanto para el ciudadano de la polis hay un deber de participación en la justicia y el gobierno de la ciudad ${ }^{88}$. La concepción del hombre puede definirse como "estar junto a", pertenecer a una comunidad es la manera en la que se encuentra la natural realización personal.

Los estoicos son parte importante de pensamiento de la antigüedad, fueron filósofos y políticos que pusieron al deber en un lugar central de su sistema de pensamiento de fuerte moralidad; vale la pena citar a Zenón, Cicerón, Séneca y Marco Aurelio. Roma profundizará el concepto de ciudadanía y sus deberes inherentes a través de sus instituciones jurídicas. Cicerón dedicó una obra completa a los deberes de los ciudadanos que se conectan directamente con la virtud. José Guillén Cabañero explica en la Introducción del libro, que él mismo traduce, que Cicerón "En el De Officiis trata de formar a todos los ciudadanos en la conciencia de lo recto y del cumplimiento del deber de una forma consciente y racional. Considerando que todos y cada uno que sus primeras obligaciones son para con la patria..." remitiendo al punto I, 57-58. ${ }^{89}$

Es interesante que Gregorio Peces-Barba relaciona directamente a Cicerón como responsable del pasaje de los deberes morales a los jurídicos, mientras que Luis Bandieri impugna esa idea..$^{90}$ Para éste último la idea de deber en los estoicos tiene un carácter exhortativo y ejemplificador, como puede advertirse de la lectura de su obra "De Officii" (lo mismo sucede con la Obra de Marco Aurelio). Coincido con Bandieri que la idea de "deberes" de los estoicos parece más vinculada y unida a la concepción de la ética como "carácter" del eudemonismo griego o a la idea de ciudadanía legal romana que al deber en sí mismo. Explica que el derecho todavía era "jus", relación de justicia entre sujetos - cosa, y que el pasaje de lo moral a lo jurídico encuentra causa en

\footnotetext{
88 Aristóteles (2007). 108.

89 Cicerón (2009).

90 Bandieri (2011). nota al pie (20).
} 
el individualismo de la modernidad, cuando el derecho cambie a "lex" y la relación sea ya sujeto - sujeto. ${ }^{11}$

En la Edad Media el sistema feudal de vasallaje se asentará sobre un sometimiento personal donde eran mucho más fuertes las cargas que las libertades, el siervo de gleba sufría una relación asimétrica con su señor y su existencia se consideraba apenas por encima de la esclavitud; al ser una sociedad y sistema productivo estructurado sobre una relación jerárquica vertical y estamentaria, no podía ser de otra manera. La filosofía medieval estará fuertemente unidad a la teología y los deberes tendrán una vinculación directa a lo religioso que se mantendrá hasta la modernidad. Así, avanzada la Edad Media, las grandes monarquías acrecentarán su poder imponiendo fuertes obligaciones a sus súbditos, situación que nos llevará a las revoluciones burguesas de la Modernidad.

El renacimiento italiano pondrá al hombre en centralidad, recuperará a los autores antiguos y dejará todo preparado para el imperio de la razón. La Modernidad irá separando al deber primero de la religión, para luego separar a los deberes morales de los jurídicos. El individualismo del hombre europeo moderno permite el pasaje de un derecho como búsqueda de lo justo en la relación sujeto-objeto a un derecho en el que el individuo se posiciona frente a las normas ${ }^{92}$. Varios elementos jugarán para que en este período se defina al Derecho como "facultad" o "potestad; se trata del Derecho "subjetivo", que se definirá en forma antinómica a los deberes. Explica Luis Bandieri, ${ }^{93}$ que de esta manera lo jurídico pivoteará sobre la subjetividad que se traduce en la primacía del Derecho potestad.

El racionalismo e individualismo moderno infiltran el ámbito jurídico para alumbrar al Derecho subjetivo. Michel Valley analiza esta conversión del ius en lex, del Derecho proporción objetiva de lo justo al Derecho como potestad subjetiva. Para este giro será importante primero el "rasero" de Ockham y su nominalismo en la cuestión de los "universales, y un individualismo metafísico que se trasladará a un subjetivismo jurídico ${ }^{94}$; Massini Correas indica que si solo existen sujetos individuales, trasladado al campo jurídico implica que el derecho se

91 En igual sentido, al seguir a Finnis, ver Massini (2010). 66.

92 Peces-Barba (1987).

93 Bandieri (2011). 7.

94 Contreras Peláez - Pérez Luño (2009). 3. Recomiendo este excelente ensayo para adentrarse en el pensamiento de Michel Villey sobre los derechos subjetivos. 
reduce a las potestades o prerrogativas de estos sujetos individuales. ${ }^{95}$ Además considera que la participación de Ockham en la disputa sobre la pobreza entre el Papado y la orden Franciscana como una temprana formulación Derecho como potestad (todavía estamos en el Medievo).

Juegan un papel importante en este giro del derecho los aportes de la segunda escolástica española; autores como Suárez y Vitoria, quienes ya consideran al derecho subjetivo como potestad de reclamo o exigencia (y como parte de la moral). Villey es excesivamente contundente en atribuir a estos autores una postura pragmatista y el abandono del preciado objetivismo. Si bien parten de una escolástica tomística, en Suárez se filtraría el voluntarismo en sus consideraciones sobre la voluntad legisladora. Por el lado de Vitoria define el Derecho como la acción justa moralmente debida y reflejada en forma de facultades subjetivas. Sin duda que estos elementos se van perfilando y contribuyen al giro de la modernidad hacia el subjetivismo jurídico, aunque entiendo que de una manera mucho más matizada que la que atribuida por Villey. ${ }^{96}$

La era de la razón también producirá las corrientes de Derecho Natural Racional. El iusnaturalismo racionalista de pensadores como Grocio también realizará su aporte, y por supuesto, Kant. Su ética formal de cumplimiento del deber solo por el deber a partir del imperativo categórico que el hombre se legisla a sí mismo a través de la razón profundizará el individualismo. El deber moral se desprenderá del deber jurídico, un ámbito se interior, el otro exterior. Para el deber de legalidad de la conducta externa se necesita la ley de la voluntad legisladora.

El contractualismo también tendrá un aporte importante en el posicionamiento del Derecho subjetivo como central y la atenuación de la idea de deber. Thomas Hobbes plantea un estado de naturaleza o presocial en el cual los hombres tienen derechos infinitos, en busca de la supervivencia, pero estos no son eficientes, operativos; la situación de beligerancia natural hace que si todos colisionen. El contrato social, que crea al famoso Leviatán, implica en definitiva un recorte de potencialidad de los derechos del estado de naturaleza que los hace eficaces, así los derechos civiles resultan finitos pero operativos y se confía su tutela al Estado, que por no ser parte del contrato, no está

95 Massini Correas (2005). 83.

96 Analizar el aporte de la escolástica española excede a este trabajo, pero no puedo no mencionar que la lectura de estos autores es de vital importancia para la filosofía del Derecho. 
obligado por ellos. Villey entiende que bajo la impronta de un aparente totalitarismo, en la concepción de Hobbes ${ }^{97}$ subyace una impronta liberal e individualista. No obstante la legitimación contractualista de Hobbes hacia el Estado será argumento de legitimidad política para las fuertes monarquías europeas.

Una cuestión clave será el absolutismo político y su caída. La razón disparará el desarrollo de las ciencias, están los grandes descubrimientos científicos y geográficos, las materias primas del nuevo mundo serán procesadas en los talleres europeos y un nuevo protagonista ganará el escenario socio-político revelándose contra el absolutismo y su pesada carga. Para el ciudadano burgués lo importante será limitar el poder del Estado que lo agobia, lo que dará origen a los derechos subjetivos como cartas de triunfo a oponer contra la autoridad. A partir de la Declaración de los Derechos del Hombre y el Ciudadano de 1789, todo girará en torno a los derechos.

Con todos los elementos que se vienen mencionando, las grandes revoluciones burguesas pondrán su acento en los derechos subjetivos como modo de protección de los ciudadanos frente al Estado. La Revolución Francesa de 1879 tuvo que realizar una elección que resultó fundamental, y sin dudas "hija de su época". Al momento de decidir el contenido de la Declaración de los Derechos del Hombre y el Ciudadano, que es más amplia que la difundida reducción a la tríada libertad, igualdad y fraternidad, se puso en evidencia la opción por una antinomia entre derechos y deberes no sin una ardua disputa en el seno de la Asamblea Nacional. Varios proyectos incluían una declaración de deberes; Henri Grégoire, más conocido como "el abate Grégoire", que además fue un defensor de la igualdad de razas, impulsó uno de ellos, pronunciándose de esta manera: "Los deberes no derivan de los derechos... Son correlativos y marchan por líneas paralelas. Es imposible concebir derechos activos sin derechos pasivos, y estos últimos son los deberes... La Constitución que haréis será una consecuencia tanto de los deberes como de los derechos. La Declaración que será el preliminar debe poner, pues, los fundamentos de unos y otros...; mostradle no solo el círculo que puede recorrer, sino también la barrera que no puede salvar" ${ }^{\prime 8}$

97 Massini Correas explica que para Finnis el punto de inflexión en el cambio ius-lex es Hobbes y agrega en nota (35) que así como para Villey tal punto es Ockham, Alejandro Guzmán Brito lo ubica en el pensamiento de un discípulo de este, Johannes Charlier de Gerson. Massini Correas (2010). 68

98 Carbonell (2009). 63. 
El diputado De Sinety también presentó un proyecto que, a modo de tabla de doble entrada, formulaba Derechos y deberes; pero lo cierto es que llegado el momento de decidir si se incluían o no los deberes en la Declaración, la votación fue contraria a ésta posición, y si bien hubo distintas razones, como bien anota el Dr. Bandieri, se fijó una postura, que sería tendencia en adelante, que al presentar a los derechos en forma antinómica con los deberes, para reforzar a los primeros se ocultó o ignoró a los segundos. ${ }^{99}$

Las primeras Constituciones de los Estados se realizaron sobre el eje fundamental del derecho subjetivo como límite al Estado, cartas de declaraciones de libertades y garantías que implicaban indirectamente el deber de respetarlos, de no interferir con tales prerrogativas.

Como ya dijimos, luego de la II Guerra Mundial la humanidad se avocó a analizar las atrocidades vividas y algunos de sus frutos fueron la creación de organismos internacionales como la Organización de las Naciones Unidad en 1945; se gestó en su seno otra Declaración, seguramente la más emblemática a nivel mundial, la Declaración Universal de los Derechos Humanos de la ONU. También en esta ocasión se presentó la cuestión de los deberes y si debían ser incluidos. La tendencia de su invisibilidad se mantendría.

El recorrido histórico nos llevará a ver ciertos instrumentos de suma importancia; en este trabajo no los analizaremos, pero sí me interesa reseñarlos e incluirlos como mojones claves, puntos de anclaje sobre los que se pueda asentar una vuelta a la consideración de los deberes humanos, y no solo estos, también deberes éticos y jurídicos.

Ya al año siguiente, 1946, se creó la Comisión de Derechos Humanos (dependiente del ECOSOC) cuya primera misión era elaborar una gran Declaración de Derechos Humanos que en principio debía incluir tres documentos: una declaración, un pacto y un tercer documento con herramientas de protección de los derechos contenidos en los dos primeros. La tarea no sería fácil puesto que el mundo ya empezaba a convivir con una política internacional dividida en dos grandes bloques, encabezados por EEUU y la URSS, que mantendrían por décadas una "guerra fría" que no fue solo ideológica, y que por supuesto se trasladó a las deliberaciones de los contenidos. 
La obligatoriedad de la Carta y sus contenidos empezaron a dividir las posturas y a poner en tensión a las potencias enfrentadas. Se nombró un Comité Inicial o "Comisión Nuclear" y luego un "Comité de Redacción"; la tarea final fue encabezada por René Cassin, quien lo presentó en 1947, y llevó todavía un año más de deliberaciones poder afinar el texto. ${ }^{100}$ En ese contexto de deliberación, negociación y definiciones, un alma mater de la DUDH, Eleanor Roosevelt fue consultada al respecto de los deberes humanos en un contexto histórico en el que los totalitaristas perdedores de la II Guerra habían utilizado un discurso ideológico impregnado de deberes hacia el Estado; su respuesta (en palabras de René Cassin) es todo un resumen del pensamiento del momento: "La tarea que se nos ha encomendado es la de proclamar los derechos y las libertades fundamentales del ser humano ... no la enumerar sus deberes". ${ }^{101}$

Todo terminó en una muy tenue mención de los deberes en el texto de la DUDH ${ }^{102}$; en su artículo 29 inciso 1 se determina que las personas tienen deberes respecto de la comunidad, fundado en que solo en ella pueden desarrollarse plenamente.

A nivel interamericano hubo un mejor reconocimiento. En mayo de 1948 en el seno de la Organización de Estados Americanos, y anticipándose a la Declaración Universal, se consagró la Declaración de los Derechos y Deberes del Hombre. Si bien su alcance es regional es un antecedente clave en un mejor reconocimiento de los deberes humanos, que ya desde su título incluye a los deberes. El Preámbulo indica que "El cumplimiento del deber de cada uno es exigencia del derecho de todos. Derechos y deberes se integran correlativamente en toda actividad social y política del hombre. Si los derechos exaltan la libertad individual, los deberes expresan la dignidad de esa libertad. Los deberes de orden jurídico presuponen otros, de orden moral, que los apoyan conceptualmente y los fundamentan."

Es interesante que la tal como se expresa, los deberes no serían un constreñimiento de la libertad sino su afirmación, tal como indi-

\footnotetext{
100 Oraá (2004). 127.

101 Oraá (1998). 454, nota (5).

102 Hubo una presión al respecto de los países del bloque socialistas y los sudamericanos, debiendo advertirse que en el mismo año 48 y unos meses antes la OEA realizó su Declaración de los Derechos y Deberes del Hombre.
} 
ca Gianluigi Palombella. ${ }^{103}$ Luego le dedica el capítulo II a "Deberes"; Su contenido se resume en deberes ante la sociedad, para con hijos y padres, de instrucción, de sufragio, obediencia a la ley, servicio a la comunidad y Nación, de asistencia y seguridad social, de pagar impuestos, trabajo y de abstenerse a realizar actividades políticas en país extranjero. Es sumamente destacable este texto importantísimo del sistema Interamericano, con aporte fundamental de los países latinoamericanos, quienes más fuerza hicieron luego, sin éxito, para incluirlos también en la DUDH. Es que a nivel Interamericano no fue algo meramente formal como el art 29.1 de DUDH (una mención que se conformará con que no los excluyera), sino que en la DADDH se determinaron ciertos contenidos de los deberes humanos.

En 1963 hay un documento muy importante en el avance al reconocimiento de los deberes. La Encíclica Pacem in Terris del Pontífice Juan XXIII habla directamente de los deberes humanos. Es verdad que se trata de un documento en el marco de una religión, pero es indebido restarle importancia a las implicancias de la Doctrina Social de la Iglesia Católica, especialmente en el pensamiento occidental, pero también en el mundo intelectual socio-político en todo el mundo. ${ }^{104}$

Fundados en su propia naturaleza la persona humana tiene derechos y deberes que son universales, inviolables e irrenunciables. Esta declaración caracteriza a los derechos y deberes humanos por igual. ${ }^{105}$ Dentro de lo que denomina "las relaciones civiles", y luego de describir los derechos del hombre, la Carta Encíclica se avoca a los deberes humanos, declarando primero una conexión esencial de estos con los derechos, en base a la ley natural. Enumera en principio 3 deberes: respetar los derechos ajenos, colaborar con los demás y actuar con sentido de responsabilidad. En su explicación queda muy claro que la posición es la de considerar la correlatividad entre deberes y derechos. "Los derechos naturales... están unidos en el hombre que los posee con otros tantos deberes, y unos y otros tienen en la ley natural, que los confiere o los impone, su origen, mantenimiento y vigor indestructible."106 También alerta sobre el peligro que implica desconocer esta correla-

103 Palombella (2007). 124. Más adelante me refiero a esta idea de Palombella.

104 Lo mismo puede decirse del pensamiento de los otros dos grandes monoteísmos, la religión judía y la musulmana; las consecuencias filosóficas, éticas, jurídicas, por ejemplo, de las mismas no pueden resultarnos indiferentes.

105 Juan XXIII (1963). 9.

106 Juan XXXI (1963). 28. 
tividad, puesto que: "quienes, al reivindicar sus derechos, olvidan por completo sus deberes o no les dan la importancia debida, se asemejan a los que derriban con una mano lo que con la otra construyen". ${ }^{107}$

Los deberes humanos también serán incluidos en los siguientes puntos, cuando el Pontífice se refiera a los distintos órdenes de la convivencia, como las relaciones políticas, las internacionales y las mundiales.

En 1969 el ámbito interamericano volvió a presentar antecedentes, al dictarse la Convención Americana de Derechos Humanos, conocida también como Pacto de San José de Costa Rica, que dedica un capítulo/artículo a los deberes de las personas (cap. 5). Su enunciado expresa la correlación entre deberes y derechos, indicando en el inciso 1 que las personas tienen deberes con la familia, la comunidad y la humanidad. Sin bien no se determina un contenido específico sino que se enuncian los destinatarios de dichos deberes, lo interesante es que son deberes para las personas, para los individuos.

Los aniversarios invitan al balance reflexivo que es, sin dudas, una excelente tarea. En 1998, con motivo del 50 aniversario de la DUDH, se realiza en Valencia una reunión de expertos auspiciada por UNES$\mathrm{CO}$ con el apoyo de la Oficina del Alto Comisionado para los Derechos Humanos de la ONU y ONGs locales, con el fin de realizar un análisis profundo de los deberes y responsabilidades del hombre y los estados, partiendo de una realidad que venimos expresando desde el inicio: "Preocupado por el hecho de que cincuenta años después de la adopción de la Declaración Universal de Derechos Humanos, y la subsiguiente adopción de otros instrumentos de derechos humanos, las graves violaciones de los derechos humanos y de las libertades fundamentales y su desprecio continúan ultrajando la conciencia de la humanidad". ${ }^{108}$

La DRDH va a diferenciar los conceptos de deberes y responsabilidades, definiendo a los primeros como obligaciones éticas o morales, (no veo claro si la conjunción disyuntiva denota alternativa o equivalencia, entiendo que debería ser alternativa, y que un deber ético no es lo mismo que un deber moral, puesto que no son sinónimos, aunque reconozco que por etimología y en otros ámbitos puedan ser utilizadas como si lo fueran). Las responsabilidades como obligaciones con "fuerza legal" fundadas en el derecho internacional. Son titulares

107 Juan XXIII (1963). 30.

108 Declaración de Valencia (1998), Preámbulo. 
de estos deberes y responsabilidades los Estados, las organizaciones intergubernamentales y las no gubernamentales, las corporaciones públicas y privadas (con especial énfasis en las transnacionales), las personas, pueblos y comunidades. La declaración sobre quiénes recae la titularidad de deberes y responsabilidades es importante toda vez que pareciera que solo corresponden a los Estados, mientras que individuos y grupos sociales solo son titulares de reclamos, de derechos subjetivos sin deberes a su cargo.

La Declaración de Valencia ha detallado pormenorizadamente deberes y responsabilidades, es un jalón de referencia de enorme importancia y que sin dudas requiere un estudio aparte, dicho listado será importante y se incluirá en el último capítulo, cuando realice un pequeño esbozo de los Deberes Humanos, remitiéndome pues al apartado 5.h "contenidos de los Deberes Humanos".

En 2009 Benedicto XVI realiza una Carta Encíclica nominada "Caritas in Veritate" (Caridad en la verdad). Expresa el Pontífice, al hablar de solidaridad y desarrollo que: "La solidaridad universal, que es un hecho y un beneficio para todos, es también un deber. En la actualidad, muchos pretenden pensar que no deben nada a nadie, si no es a sí mismos. Piensan que solo son titulares de derechos y con frecuencia les cuesta madurar en su responsabilidad respecto al desarrollo integral propio y ajeno. Por ello, es importante urgir una nueva reflexión sobre los deberes que los derechos presuponen, $y$ sin los cuales estos se convierten en algo arbitrario". ${ }^{109}$ La Encíclica expresa un diagnóstico preciso sobre la no consideración de los deberes.

Expone la contradicción que existe entre los reclamos arbitrarios y superfluos de ampliación de supuestos derechos que contrastan con la violación derechos humanos elementales como el derecho a la alimentación, vivienda, agua potable, salud y educación, tanto en los países en vía de desarrollo como en el propio seno de sociedades opulentas.

Atribuye esta situación al desquicio de los derechos individuales como consecuencia de su desvinculación de un conjunto de deberes que le den sentido. Es interesante como se presenta a los deberes no solo como un límite a los derechos sino también como su fundamento de sentido profundo y real criterio que evita la arbitrariedad y el mero capricho, dotándolos de legitimidad. La exacerbación de los derechos

109 Benedicto XVI (2009). 43. 
conduce al olvido de los deberes y estos derechos carentes de sentido antropológico y ético se transforman en el resultado de la lucha de legislativa que puede ser de una manera u otra, es decir, sin más fundamentos que imponerse en el fragor deliberativo ${ }^{110}$, que hoy los reconoce pero pudiera ser que mañana no.

Al ser una opinión coincidente la que entiende que la realidad nos muestra una prioridad absoluta a favor de los derechos subjetivos que oculta e ignora los deberes, a continuación veremos algunas de las posibles causas.

\section{IDEAS SOBRE LAS CAUSAS DE LA INVISIBILIDAD DE LOS DEBERES HUMANOS}

La situación de los deberes, y específicamente los deberes humanos, y su actual invisibilidad reconoce varias razones, muchas de las cuales se han ido desarrollando. En los párrafos siguientes resumiremos algunas de ellas.

La evolución histórica nos muestra como el pasaje del derecho como lo justo hacia un derecho que toma como eje central a los derechos subjetivos ha dejado de lado a los deberes.

Ésta concepción del derecho o bien transformó a los deberes en una derivación subordinada de los derechos que facilita su cumplimiento, o los coloca en una relación de dos caras de la misma moneda en la que los deberes se transforman en su cara oculta y olvidada.

Asimismo, el hecho que los totalitarismos y autoritarismos del siglo XX hayan utilizado los deberes como parte de su discurso justificador de la subordinación del hombre a sus estructuras cargó de una mirada peyorativa y de desconfianza toda invocación que en adelante los tomará en cuenta; la respuesta que anotamos de Eleanor Roosevelt es un claro ejemplo.

Sumemos también el fenómeno de la expansión de derechos. El individualismo asociado a los derechos subjetivos ha fomentado que en los últimos años se produjera una fuerte expansión del reclamo y re-

110 Foucault (2003). El intelectual francés llevará a Nietzsche al campo jurídico, considerando al derecho como la forma ritual de la guerra (Conferencia 3). 69. 
conocimiento de derechos al margen de toda mirada de los deberes. La materia de los Derechos Humanos se ha convertido en una suerte de masa crítica que crece sin límites y con un riesgo seguro: si todos los derechos (o su mayoría) se transforman en derechos esenciales y fundamentales se difumina la jerarquía de los mismos y se igualan al resto de los derechos, perdiendo el acento de consideración que deberían despertar para producir reconocimientos y transformaciones reales. Además de opacar la su relevancia, la ampliación desmesurada de derechos humanos termina por incluir reconocimientos cuestionables, en los que su esencialidad respecto la dignidad del hombre luce banalizada, licuada. Es muy claro Carlos Maino cuando dice: "Cuando todos los derechos se tornan fundamentales, se termina ninguneando la ley. Además, si todos los derechos son fundamentales, y es imposible distinguirlos de los ordinarios, recibirán todos el mismo tratamiento igualitario, en desmedro de la importancia y excepción que los derechos humanos realmente merecen". ${ }^{111}$

A esta situación de expansión que conlleva a una pérdida de jerarquía y banalización de su contenido sumemos una muy importante consecuencia problemática: todo es ampliación de derechos, de potestades, de reclamos, pero al no hablarse de deberes todas estas prerrogativas no encuentran ya receptores porque nadie se siente obligado. Si en la misma medida en que ampliamos derechos olvidamos ocuparnos de los deberes, la pregunta es ¿quiénes los satisfarán? ¿Todo recaerá en el Estado, suerte de blanco fijo de reclamos al que todas las flechas parecieran alcanzar? ¿Qué pasa con la invisibilidad de nuestros deberes individuales? Casi como dándole la razón a John L. Mackie ${ }^{112}$ en cuanto a que los deberes son algo molesto, González Faus caracteriza nuestra época indicando que "...lo habitual es usar los derechos humanos no como una fuente de deberes míos, sino como fuente de reivindicaciones para mí y de obligaciones "para los demás", como excusa para exigir algo a otros, que es una de las cosas que más nos gustan a los humanos..." ${ }^{113}$

William Daros remarca como factor contribuyente la posmodernidad y su pulverización de los grandes relatos, con los que también desaparecen los grandes deberes universales. ${ }^{114} \mathrm{El}$ análisis es interesante, en efecto la concepción de la "verdad" como solo un conflicto de

\footnotetext{
111 Maino (2011). 16.

112 John Leslie Mackie.

113 González Faus (2002).

114 Daros (2013). 30.
} 
discursos y la caída de los grandes metarelatos de la posmodernidad (iluminismo, cristianismo, marxismo, capitalismo) ha llevado a una concepción del hombre y la sociedad que se asienta ahora en microrelatos, en un sinfín de diversidades y minorías que reclaman sus derechos, su visibilidad; desde la perspectiva del Derecho ha acrecentado una explosión de derechos subjetivos que no fueron acompañados en su irrupción por el correlato correspondiente de deberes, lo que contribuyó a la expansión de la pléyade de facultades de los nuevos colectivos humanos, que se perciben como merecedores de respetos pero que no se reconocen como titulares de deberes.

Gilles Lipovetsky ${ }^{115}$ analiza esta "ética indolora" en la que el deber ha perdido todo sustento. Atado a la religión en sus orígenes, el proyecto secularizador de la modernidad reemplazó a estas por un fundamento humanista y racional que luego también se fue licuando en el vacío del hiperindividualismo narcisista y consumista, donde la imagen y el hedonismo dejan poco lugar al compromiso. "Se ha puesto en marcha una nueva lógica del proceso de secularización de la moral que no consiste solo en afirmar la ética como esfera independiente de las religiones reveladas sino en disolver socialmente su forma religiosa: el deber mismo." 116 Para Lipovetsky los valores sacrificiales y de abnegación que implicaban los deberes han desaparecido y las democracias actuales se han organizado a partir de una posmoral que implica una ética mínima, sin obligación ni sanción.

No es de extrañar entonces que luego de todos los elementos mencionados, el Derecho haya prácticamente prescindido de los deberes para aplicarse afanosamente al desarrollo de los derechos subjetivos. Ésta es otra concausa del ocultamiento de los deberes y se refleja claramente en que los diferentes Documentos Internacionales no los considera y si lo hacen son menciones casi vergonzosas y mínimas, al punto que el trabajo recopila casi un rastreo de lupa para ubicar declaraciones que los reconozcan. Y lo mismo ocurre con la doctrina. La labor sobre deberes, comparativamente con el desarrollo de derechos, es insignificante.

115 Lipovetsky (1994). 32.

116 Lipovetsky (1994). 12. 


\section{APROXIMACIÓN A LOS DEBERES}

Ya en su obra "Introducción Filosófica al Derecho" Werner Goldschmidt realizaba una severa advertencia acerca de un problema con el que se debería lidiar en Derecho: la multivocidad doble de los vocablos $^{117}$, o en palabras de Massini Correas: "En esta tarea analítica acerca de la noción de derechos ... hay que reconocerlo, existe un cierto desorden terminológico, pues se utilizan palabras diferentes para significar nociones idénticas" ${ }^{118}$. No en vano los filósofos del giro lingüístico trabajan arduamente sobre los desacuerdos del lenguaje y de la misma manera la Meta-Ética intenta precisar los conceptos de la disciplina. En efecto al analizar el tema del deber tanto en el campo ético como jurídico vamos a encontrar distintos significados, alcances e interpretaciones para las mismas palabras y estructuras lingüísticas. Trataremos de reducir y simplificar ciertos conceptos, puesto que este trabajo no tiene como objetivo abordar dichas cuestiones (arduas y necesarias).

La idea de deber nos remite a obligación, a estar atado (ligado) a otra persona porque tenemos que realizar (o no realizar) una acción a favor de este. En su etimología latina la palabra deber viene de "debere" componiéndose con el prefijo "de" y - habere, significando tener la cosa de otro, a quien hay que devolvérsela. Esto implicaría una limitación a nuestra libertad ${ }^{119}$ (no física, sino moral) que no puede eludirse, o al menos no sin consecuencias; un mandato a tomar una decisión respecto del cumplimiento de lo debido. Los deberes serán económicos como sociales, familiares, morales religiosos y jurídicos, según de cuál sea su fuente o contenido. Incluso un mismo deber puede ser a la vez moral, social y jurídico, o religioso y moral.

William Daros, siguiendo a Antonio Rosmini, considera al deber una exigencia moral de justicia; si el deber implica etimológicamente "de - habere", tener la cosa de otro, será necesario una acción de devolución, la misma consiste en dar a cada uno lo que corresponde; el deber es pues una exigencia de acción que impone la justicia a la conciencia que confronta. ${ }^{120}$

\footnotetext{
117 Goldschmidt (1978). 1

118 Massini Correas (2005). 105.

119 Pensadores como Palombella ven en el deber no como una restricción negativas a la libertad sino que por contrario, tienden a ampliar la libertad. Más adelante volveré al tema.

120 Daros (2013). 18.
} 
Ahora bien el deber se presenta ante la persona como una confrontación entre lo que puede hacer y lo que debe hacer, y si bien el deber puede verse como un constreñimiento a la libertad, la supone; implica para la conciencia del hombre una obligación a cumplir. En el campo moral obliga a conciencia; para ser socialmente exigida ese deber debe haberse convertido en costumbre y si es reconocido por el Derecho, estamos en campo jurídico. ${ }^{121}$ Las relaciones entre moral y Derecho son estrechas para gran parte de las concepciones del derecho; en cuanto al deber, no es posible no incluir la religión como componente ineludible en su elaboración original en la antigüedad. Pero es fundamental que quede correctamente delimitado que si bien pueden superponerse, los deberes morales y jurídicos se distinguen.

El deber jurídico es el que tiene un soporte jurídico; encuentra en el Derecho, en una norma jurídica del Derecho positivo su origen y determinación, exigiendo su cumplimiento objetivo y exterior. Es verdad que hay un deber moral de cumplir con el Derecho, pero se trata de un deber moral, cuyo fundamento está en valores contenidos en las normas morales. Coincide en este caso el deber jurídico con el deber moral de cumplir con el Derecho (es un tema no menor la validez del Derecho). También puede ser que el contenido del deber jurídico sea un deber moral. Vemos a un ejemplo: i. existe un deber jurídico de asistencia alimentaria a los hijos, ii. hay un deber moral de cumplir con el Derecho, y iii. además el contenido del deber jurídico (procurar alimentos y asistencia a los hijos) es un deber moral. Pagar una deuda documentada es un deber jurídico, que encuentra su origen en una norma jurídica civil/comercial, también es un deber moral honrar las deudas; puede suceder que la norma jurídica extinga el deber jurídico por el paso del tiempo, pero subsiste el deber moral de afrontar la misma (en Derecho las llamamos obligaciones naturales). Lo mismo sucede con las normas sociales, puede haber coincidencia o no entre el contenido del deber social y el contenido del deber jurídico. Distintas normas (morales, sociales, jurídicas) son fuentes de distintos deberes (morales, sociales, jurídicos), que puede superponerse, o no. ${ }^{122}$

La fuente del deber jurídico es una norma jurídica, ahora bien, hay algo que distingue a la norma jurídica y es la coercibilidad, la posibilidad de ser aplicada por medio de la coacción; un deber jurídico incumplido genera la posibilidad que se fuerce su cumplimiento o se

121 Daros (2013). 17.

122 Recaséns Siches (2000), Cap. VIII. 
ordene reparar el incumplimiento, pero lo importante es que genera consecuencias sancionatorias. Si no existe esta posibilidad, no es un deber jurídico. Esta concepción sitúa a la sanción como un elemento necesario y decisivo para la determinación del deber jurídico, siendo la clásica posición de Kelsen. ${ }^{123}$ "Por el contrario, no hay obligación jurídica de conducirse de una manera determinada sino en el caso que una norma jurídica estatuya un acto coactivo para sancionar la conducta contraria."

La postura que considera que sin sanción no hay obligación o deber jurídico generó un matiz en cuanto a si la sanción debería implicar una situación más gravosa que produzca una repugnancia a la desobediencia, o bastaba que la sanción produzca en el obligado la necesidad de evitar las consecuencias negativas que el ordenamiento jurídico atribuye al incumplimiento. ${ }^{124}$ Explica Ana Colomer Segura, siguiendo a Vidal, que "con la llegada del positivismo jurídico, se reduce el deber a la coacción" ${ }^{125}$, resumiendo correctamente todo un pensamiento jurídico muy influyente.

Para Moisset Espanés ${ }^{126}$ el deber moral también genera sanciones para el caso de su incumplimiento, solo que son sanciones de otra naturaleza, como el repudio social o el remordimiento individual; no obstante queda claro que no puede ser forzado su cumplimiento, esto es, cumplidos coactivamente.

Pero no solo la presencia de la sanción distingue a estos deberes morales de los jurídicos, ambos campos proporcionan otras diferencias que se integran y complementan. La moral impone deberes subjetivos a la conciencia del sujeto y por tanto unilaterales, mientras que los deberes jurídicos siempre importan una relación bilateral puesto que el campo jurídico es la conducta humana en convivencia y la nota de alteridad es evidente; el deber involucra no solo al sujeto que actúa sino también al resto de los individuos de la sociedad con las que dicho actuar se relaciona.

La ética, la religión, el Derecho, en fin, toda la conducta humana solo puede considerarse a partir de su libertad y esta solo se entiende

\footnotetext{
123 Kelsen (2009). Cap. IV. 66.

124 Escobar Rozas (1999). 294.

125 Colomer Segura (2012). 2.

126 Moisset de Espanés (1966).10.
} 
a partir de la dignidad del hombre; de esta dignidad brotan derechos, pero también deberes. Derechos Humanos y Deberes Humanos.

Los derechos, en sentido subjetivo, son facultades, potestades que se reconocen al hombre de poder reclamar, peticionar lo que le corresponde, lo que es justo. Estamos en el orden de los derechos subjetivos pero tal como los conocemos los derechos subjetivos son un producto de la modernidad, un reconocimiento de la individualidad frente al poder del Estado que hirvió al calor de las revoluciones burguesas y del pensamiento iluminista y en este contexto es Kant quien logra un desarrollo que separará al deber moral del jurídico.

Los derechos de la primera generación reconocen las libertades negativas, la potestad de reclamar la no interferencia sobre dicho derecho (su ejercicio) con lo cual, por ejemplo, mi derecho a la integridad física implica que nadie puede menoscabarla; ese derecho se relaciona con el deber del resto de las personas de no afectarlo. Derecho ${ }^{127} \mathrm{y}$ deber son, según esta mirada, dos caras opuestas de la misma moneda. El derecho de A implica el deber de B de no impedir o interferir el ejercicio de dicho Derecho. Así se ha conformado una fuerte doctrina que encuentra una relación estrecha entre Derecho y deber, pero diferenciándose en cuanto a si dan primacía a uno u otro, o si ambos están en igualdad.

En algunos autores los derechos son previos a los deberes, así Eusebio Fernández reconoce la relación de correlatividad entre derechos y deberes indicando que poseer un derecho implica que el ordenamiento jurídico a impuesto un deber correlativo y complementario a otra persona pero aclara que los derechos son "lógica y axiológicamente anteriores a los deberes, pues determinada una necesidad incondicional así como las posibilidades reales de satisfacerla, se puede establecer el deber correlativo, por lo que los derechos justifican los deberes." ${ }^{28}$ Analizando los fundamentos de la moralidad John Leslie Mackey ${ }^{129}$ indica que pa-

127 Respecto de la voz "derecho" queda claro que sus concepciones son amplísimas y que tomo en cuanto a su concepto la idea de derecho subjetivo, reduciendo la cuestión puesto que sería de notable extensión analizar el concepto de Derecho.

128 Fernández (1984).

129 John Leslie Mackie, filósofo moralista australiano, en su artículo "¿Puede haber una moral basada en el derecho?". 168-181, en el libro "Theories of Rights”, coord. por Jeremy Waldron (1984), ed. Oxfords Readings in Philosophy. Citado por Massini Correas (2005). 102. 
reciera que una moral basada en derechos es mejor que una basada en deberes puesto que los derechos son algo que todos desean mientras los deberes nos resultan fastidiosos, salvo que les sean impuestos a los demás, y solo en miras a las ventajas que implican para nosotros o nuestros amigos; un deber por el deber mismo es una absurdo y realizará una defensa de la primacía del derecho sobre el deber.

Otros autores que colocan a los deberes en un grado de prelación respecto de los derechos, como Simone Wiel. Para esta pensadora francesa el hombre considerado desde sí mismo solo posee deberes y tiene derechos solo cuando aparece el punto de vista de los demás, es la convivencia con otros la que genera derechos; un hombre solo, solo posee deberes. Hay que tener en cuenta que el pensamiento de Weil se forjó durante la II Guerra Mundial, exiliada en Inglaterra y sufriendo por la situación de su patria. El primer párrafo de su libro L’Enracinement es ahora muy citado cuando se busca recuperar la importancia de los deberes: "La noción de obligación prima sobre la de derecho, que está subordinada a ella y es relativa a ella. Un derecho no es eficaz por sí mismo, sino solo por la obligación que le corresponde. El cumplimiento efectivo de un derecho no depende de quién lo posee, sino de los demás hombres, que se sienten obligados a algo hacia él. La obligación es eficaz desde el momento en que queda establecida. Pero una obligación no reconocida por nadie no pierde un ápice de la plenitud de su ser. Un derecho no reconocido por nadie no es gran cosa". ${ }^{130}$

Gianluigi Palombella encuentra en las libertades positivas una posibilidad de fundamentar deberes no ya como un constreñimiento a la libertad sino como realización de autonomía personal; así el respeto a ciertos valores o bienes se impone por su relevancia y no por correlatividad de ese deber con derechos; poniendo como ejemplo los deberes emergentes de las relaciones de amistad; este deber, como lúcidamente expone, "no representa una limitación a nuestras posibilidades de elegir ... no se trata de un freno que debemos imponernos por respeto a los otros ... sino que se trata de nuestra visión del mundo, el efecto de una concepción de la humanidad, y de la vida, de su sentido". ${ }^{131132}$

130 Weil (2000). 19.

131 Palombella (2007). 124.

132 Tomo el fragmento del ensayo de Palombella a partir de su reseña por Ana Colomer Segura en Colomer Segura (2012). 3. 
Este autor expresa que la relación entre derechos y deberes es al menos controvertida, aun reconociendo que se trata de un paradigma recurrente. Entiendo que hay una relación estrecha entre derechos y deberes, la que no se diluye aun si aceptamos la idea que no siempre un deber se deriva o conecta con un derecho (a la vez muchos deberes se presentan vinculados lógicamente a derechos). Esta intervención nos ayuda a sumar al análisis la idea del deber como promotor de derechos, y en consecuencia considerar que los deberes son una ampliación de la libertad y no su constreñimiento; incluso estas nociones pudiendo ser opuestas no son contradictorias, como explicaré más adelante.

También es interesante mencionar que Palombella analiza el porqué atribuimos prioridad a los deberes o a los derechos llegando a la conclusión que la prioridad vendrá determinada por la concepción que se tenga de la moral política o la moral general. "¿cuáles son las razones por las que atribuimos prioridad a los deberes o, alternativamente, a los derechos? La respuesta depende de la concepción que se tenga de la moral política o de la moral en general: si las normas morales pueden tener una justificación que encuentre apoyo en los derechos o en los deberes, o quizá finalmente, en una tríada habitual, en el bien público (right-based, duty-based o incluso goal-based)." ${ }_{133}$

La idea de ver entre derechos y deberes una relación estrecha de correlatividad y complementariedad luce fuertemente intuitiva si consideramos los derechos de primera generación, estos giran en torno a la no interferencia de la autonomía individual, lo que implica que por cada derecho subjetivo hay un deber negativo de todo un universo restante de no afectar la libertad reconocida. No obstante no pueden confundirse, mientras los derechos son posibilidad de acción (o no acción) los deberes son obligación de acción o abstención. La cuestión más ardua se presentará cuando poco a poco se desarrollen deberes positivos, es decir, la obligación de hacer cuya aceptación no es tan pacífica en ningún ámbito. Un análisis profundo de esta postura y sus críticas puede verse en el trabajo de Horacio Spector. ${ }^{134}$ Por su parte Massini Correas entiende que del análisis de los derechos se desprende que no es posible pensarlos sin suponer un necesario deber jurídico de otro u otros sujetos, aunque sean indeterminables (idea que viene de sus análisis de contraejemplos), y funda su posición en una cuestión lingüística que sugiere una incorrecta relación ju-

133 Palombella (2007). 121.

134 Spector (2001). 15. 
rídica; cuando se habla de "derecho a" parece remitir a una relación de dos términos: el sujeto y el objeto, mientras que la relación es de tres términos: titular, objeto y obligado, al no reflejar la terminología empleada la verdadera relación jurídica aparecen los errores que ocultan la relación entre derechos y deberes. ${ }^{135}$

Puestos a buscar un fundamento que reconozca la importancia de derechos y deberes sería interesante proponer que en cuanto a derechos humanos y deberes humanos, ambos encuentran fundamento en el reconocimiento de la dignidad de la persona humana ${ }^{136}$; el valor del ser humano lo hace titular de derechos y de deberes fundamentales que deber ser reconocidos y respetados. Integrados y correlativos, derechos y deberes deben considerarse en pie de igualdad en cuanto a su origen y respeto.

La Encíclica "Paz en la Tierra" (1963) del Papa Juan XXIII pone a la Doctrina Social de la Iglesia Católica en consonancia con la idea de la correlatividad de los derechos y deberes del hombre, con fundamento en la su dignidad: "En toda convivencia humana bien ordenada y provechosa hay que establecer como fundamento el principio de que todo hombre es persona, esto es, naturaleza dotada de inteligencia y de libre albedrío, y que, por tanto, el hombre tiene por sí mismo derechos y deberes, que dimanan inmediatamente y al mismo tiempo de su propia naturaleza. Estos derechos y deberes son, por ello, universales e inviolables y no pueden renunciarse por ningún concepto" ${ }^{137}$

Los deberes no son solo la cara oculta o menos famosa de un derecho. Aunque debe advertirse que el acento que se ha puesto en el reconocimiento de derechos y su protección no tuvo respecto de los deberes el mismo desarrollo. Las razones de la invisibilidad de los deberes humanos son varias y la idea de dar por sentado los deberes solo como contracara de los derechos quizás no ayudó a su consideración.

Al volver a Weil, la francesa continua se texto esbozando una idea de "deberes humanos" como aquellos deberes que tenemos hacia otros

135 Massini Correas (2005). 103-104.

136 La idea de la dignidad humana, a la que adhiero y considero punto de partida de los derechos y deberes humanos, puede tener distintos contenidos en cuanto a qué es lo valioso que caracteriza al hombre (su filiación religiosa, su racionalidad, su moralidad, etc.) Bobbio directamente elude la cuestión de la fundamentación para centrarse en la protección del sistema de derechos humanos.

137 Juan XXIII (1963) Pacem in Terris, punto 9, 28-34. 
seres humanos por el solo hechos de serlo y en forma incondicionada; una obligación eterna que responde al destino del ser humano, e implica un respeto hacia el hombre y sus necesidades más importantes.

Es fácil relacionar el contenido de los deberes humanos de Simone Weil con la clásica definición de Peces-Barba sobre deberes fundamentales: "Aquellos deberes jurídicos que se refieren a dimensiones básicas de la vida del hombre en sociedad, a bienes de primordial importancia, a la satisfacción de necesidades básicas o que afectan sectores especialmente importantes para la organización y el funcionamiento de las instituciones públicas, o al ejercicio de derechos fundamentales, generalmente en el ámbito constitucional" ${ }^{138}$ La doctrina fue acuñando la expresión "deberes fundamentales" que figura en varios textos constitucionales de distintos países, como por ejemplo Italia. La cuestión de su nominación también deberá esclarecerse, ya que muchas veces se utiliza como sinónimo de Derechos Humanos, pero también se la utiliza para denominar a los derechos que por ser considerados de vital importancia para el desarrollo individual y social de las personas, se incluyen positivizados en el texto constitucional de un Estado. La cuestión es que dichas positivizaciones denominadas "Derechos Fundamentales" suelen ser mucho menos amplias que el plexo de Derechos Humanos, es decir, no todos los DDHH se encuentran en esa consideración de Derechos Fundamentales, lo cual no es un dato menor. Pero además muchos autores han detallado diferencias importantes en cuanto a su origen, naturaleza, protección absoluta o relativa, límites y regulación. Tratar ésta cuestión no es objeto de éste trabajo, por lo que solo dejo expresado el planteo.

Los deberes se fueron clasificando metodológicamente en distintas especies a medida que su desarrollo se profundizaba, especialmente en el ámbito de ética.

Una de ellas es muy significativa, los deberes negativos son los que nos ordenan no realizar ciertas conductas mientras que los positivos nos obligan a actuar de alguna determinada manera. Mientras los primeros se presentan ante nuestra conciencia de modo menos complicado, no ocurre lo mismo con los positivos. Yo puedo cumplir con mis deberes negativos quizás sentado en casa viendo deportes y de hecho no estoy interfiriendo la libertad ambulatoria de otros. Los deberes positivos imponen una determinada conducta, un hacer y se nos

138 Peces-Barba (1987). 336. 
platea la cuestión de su límite. Supongamos que se nos presenta una persona que necesita nuestra ayuda, cuál es el límite dinerario de mi ayuda o debo darle todo lo que necesita aun al costo de ruina económica. Si la ayuda es física, por ejemplo debiendo rescatar a una persona que ha caído a un río, ¿hasta donde llegará mi deber, será arrojar un salvavidas, o avisar al bañero, o deberá arrojarme al remolino de agua para rescatarlo? ¿¿Debe el Vaticano vender todo su patrimonio y el producido darlo a los menesterosos? Cuando la ley prescribe un deber positivo, ¿con qué alcance puede hacerlo? Si la constitución determina que el Estado debe garantizar el acceso a una vivienda digna, ¿se trata de un deber positivo sin límites? ¿Cómo repercuten las distintas concepciones del deber en el Estado Bienestar, en las asociaciones intermedias y en los individuos?

Los deberes imperfectos son los que admiten distintos modos de cumplimiento, por ejemplo puedo dar personalmente dinero o ropa, alimentos a un necesitado, o trabajar en una ONG que se ocupe de tareas sociales, incluso puedo elegir en ayudar a los necesitados de mi barrio, o a los de África, o a las madres solteras o niños huérfanos; por contrario los deberes perfectos no permiten elegir el modo de cumplimiento, por ejemplo si debo respetar la libertad de opinión o preferencia sexual, no puedo optar con quien cumplo y con quien no cumplo, con cual grupo o persona satisfago dicho deber; el deber no dañar la integridad física de una persona no permite tales digresiones sino que se presenta conminando un cumplimiento sin opciones.

De la lectura de estos pares de conceptos se desprende que los deberes negativos tienden a ser perfectos (por ejemplo no dañar) y los positivos tienden a ser imperfectos (actuar, es decir, hacer o dar algo a favor de una persona o grupo se apoya en un límite de selección de medios y personas o grupos de personas).

Estas categorías, deberes negativos y positivos, perfectos e imperfectos, combinadas con la de generalidad son de muy importante desarrollo y sin dudas que afectan a la consideración de los derechos positivos sociales a partir de la segunda generación y la cláusula de progresividad. Para una profundización del tema recomiendo la lectura de Garzón Valdez ${ }^{139}$ y Bayón. ${ }^{140}$

139 Garzón Valdés (1986).

140 Bayón (1986). 
Antes de continuar es conveniente dejar solo sentado que suele distinguirse al deber de la obligación, que muchas veces son utilizados como sinónimos. La obligación se entiende como una relación jurídica personal entre partes que responde a intereses privados y por la cual una de ellas tiene que cumplir una determinada prestación a favor de la otra que cuenta para exigirla con el correspondiente derecho subjetivo; mientras que el deber se establece como una expresión de protección de un determinado interés objetivo de naturaleza pública que se impone a partir de la potestad del titular del poder público ${ }^{141}$. Sin dudas que la distinción requiere profundizarse, pero escapa a los fines de este trabajo.

\section{LOS DEBERES HUMANOS}

En los puntos precedentes he tratado de describir la situación de los deberes en su recorrido histórico y las razones de lo que se considera su "invisibilidad" e incluso más aún, la indiferencia, desconfianza y resistencia que producen en muchos ámbitos, y finalmente las ideas más importantes sobre deberes. Trataré de esbozar, a continuación, una aproximación a los deberes humanos.

a. Las críticas a la noción de deberes humanos son varias, incluso son compartidas con ciertas críticas a los deberes constitucionales. Veamos algunas de ellas.

En primer lugar, se indica que sus contenidos son tan heterogéneos que es muy difícil encontrar un criterio estructurante de su concepto. Al respecto es verdad que su contenido es diverso, sin embargo se puede partir de un concepto de deber para luego identificarlos. Queda claro que hablamos de contenido, por tanto será necesario analizar los enunciados, puesto que la utilización de la palabra "deber" no siempre revelará un deber humano, siendo necesario ver la estructura lingüística en la que se utiliza.

En segundo lugar, se indica que si no tienen una sanción concreta no se trata de un verdadero deber. Ya hemos hablado en el punto anterior acerca de la concepción que estructura al deber sobre la idea de sanción. Al no tener efectos jurídicos se considera que los deberes humanos, incluso los deberes constitucionales, no tienen efectos jurídicos

141 Díaz Revorio (2011). 284. 
por lo que se trata de una categoría carente de utilidad e irrelevante y por tanto prescindible. La noción de obligatoriedad de la norma jurídica haría redundante gran parte del contenido de los deberes que solo serían reiteraciones del resto del ordenamiento. Al respecto entiendo que la noción de "sanción" como elemento estructurante de la enunciación del deber no es necesaria. Los deberes humanos tienen efecto jurídico, lo que no se opone a que funcionen como criterio de límite e interpretación para legisladores y magistrados, función de esencial importancia que también tienen los derechos humanos y que da por tierra toda atribución de ser una conceptualización irrelevante y prescindible. La redundancia que se le imputa solo implicar una mirada que tiene como eje al derecho sustantivo dándole al deber el papel secundario de ser una suerte de mera contracara que hace a la eficacia del derecho.

También, se indica que los deberes no tienen como destinatarios solo a los legisladores. No hay dudas que los deberes (y los derechos) humanos deben ser considerados como parte integrante del contenido filosófico/jurídico de la producción normativa y judicial, tanto en la fundamentación de las decisiones como en los límites infranqueables de las mismas. Tampoco ésta función se contradice con que los deberes tengan destinatarios concretos, sea un Estado o personas individuales o grupos de personas, o que funcionen además como habilitación para que los legisladores regulen un determinado deber, aunque debe quedar claro que de ninguna manera se los considerará tan solo como una mera expectativa de actuación de los poderes públicos. Ubicados en instrumentos internacionales al igual que los Derechos Humanos, su virtualidad jurídica es asimilable.

Es necesario proseguir este acercamiento sobre deberes humanos proponiendo algunas caracterizaciones al respecto.

b. Denominación: en primer lugar opto por la denominación "deberes humanos" para aquellas conductas de acción u omisión cuyo cumplimiento es impuesto a todos los individuos, grupos y Estados, fundados en la naturaleza del hombre, y cuyo contenido se integra con la satisfacción de las exigencias fundamentales de respeto y realización de la dignidad del ser humano.

Tal denominación tiene además una obvia relación con la de Derechos Humanos. Hay otras, por ejemplo cuando estos deberes son positivizados, al ser incluidos en ordenamientos jurídicos internos, probablemente se los denomine deberes fundamentales, o deberes constitucionales 
si además la norma que los reconoce es una constitución (recordando que no es solo una cuestión de nomenclatura sino que hay diferencias esenciales entre deberes humanos y constitucionales).

La Declaración de Valencia distingue entre "deberes" y "responsabilidades". Conceptualiza a los deberes como obligaciones éticas o morales y a las responsabilidades como obligaciones jurídicas. La distinción se hace eco de una importante opinión que separa a los deberes de las obligaciones en razón de considerar a estas últimas como generadoras de un reproche jurídico por su incumplimiento. También implica negar a los deberes categoría jurídica.

Tania Busch Venthur, propone aceptar la categoría de deberes jurídicos al entender por tales deberes como la imposición de una conducta sin atribuir un derecho subjetivo como potestad de exigencia directa de cumplimiento a favor de otra persona, mientras que la obligación prescribe una conducta que puede ser exigida judicialmente por un sujeto al cual se lo facultado con tal poder atribuyéndole el correspondiente derecho subjetivo. ${ }^{142}$ La tesis parece insertarse en la idea de considerar la autonomía del deber respecto de los derechos.

La Declaración de Valencia no ha tenido, por cierto, un desarrollo posterior de la distinción que propone, pero de alguna manera es consistente con la mayoría continental europea que pone acento en la sanción como elemento esencial, y por eso reserva para el deber un carácter moral.

La distinción entre deberes y obligaciones que no quita carácter jurídico al deber, aunque no lo dote de una sanción directa, resulta mejor. Además no implica negar reconocimiento al contenido ético/moral del deber. Podría entenderse que los Deberes Humanos pueden dividirse en: a. "deberes propiamente dichos" y b. "obligaciones". No obstante en derecho constitucional el "deber constitucional" funciona como categoría jurídica autónoma, aunque dirigido solo a los individuos.

c. La cuestión de la titularidad de los deberes humanos no es menor, la Declaración de Valencia es amplia en poner a cargo de los deberes y responsabilidades a la Comunidad Internacional y entender por tal a: i. los Estados, ii. Las Organizaciones intergubernamentales, internacionales, regionales y subregionales, iii. Las Corporaciones Públicas y Privadas, con inclusión de las transna-

142 Busch Venthur (2012). 45. 
cionales, iv. Otras Entidades de la sociedad civil, v. los pueblos, las comunidades, y las personas consideradas de un modo colectivo. La cuestión es importante no solo porque debemos resolver quienes son aquellos a los que un deber impone un comportamiento (activo u omisivo), sino porque también buscando una amplitud de titulares podemos volver a caer en el no deseado efecto de licuar la responsabilidad individual de las personas. Además los deberes del Estado aparecen desde ya fuertemente visibilizados y positivizados tanto a nivel internacional (tanto en Tratados Internacionales como en las numerosas normas de "soft law" que produce la comunidad internacional organizada), como a nivel del derecho nacional de los distintos Estados, a partir de los derechos humanos de segunda y tercera generación, o si se prefiere evitar la tesis generacional, a partir del constitucionalismo social o a partir de la irrupción del Estado Bienestar.

La correlatividad de los derechos y deberes humanos nos lleva a pensar a los deberes en cabeza de las personas individuales, centro de dignidad a partir del cual encontramos su fundamento y razón de ser. Asimismo, la mayoría de los documentos analizados como antecedentes también han mantenido una tradición en la misma idea. El Dr. Edgardo Ettlin opta por excluir a los Estados de la noción de deberes humanos pues considera que los deberes humanos o fundamentales parten desde las personas. ${ }^{143}$ Es indudable que esta posición percibe algo fundamental, y es que la gran invisibilidad de deberes corresponde a los que se ponen en cabeza de los individuos. Sin embargo los distintos documentos de Derechos Humanos asignan deberes a los Estados, y a partir de un concepto que implica considerar como deberes humanos a aquellos que tengan una autonomía respecto del bien jurídico que se pretende servir, consideraré al Estado como protagonista de ciertos deberes humanos muy específicos.

Por tanto, son titulares de deberes humanos las personas individuales, grupos sociales y los Estados.

d. Estatus: como Deberes Humanos reconocidos en el Derecho Internacional deberían gozar del mismo estatus que los Derechos Humanos. ${ }^{144}$

143 Ettlin (2013). 3.

144 Es conveniente recomendar la lectura de los brillantes trabajos del Dr. Ettlin, los que pueden ser ubicados a partir de la bibliografía. 
e. Correlatividad: hay una innegable e importantísima relación entre derechos humanos y deberes humanos, lo que no impide que consideremos a estos últimos como una categoría autónoma ${ }^{145}$ que pueda tener además la doble función de ser límite a la vez que promotor de derechos, justificando así cierta correlatividad entre ambos. También percibo como un error que contribuye al ocultamiento de los deberes si, en miras de la correlatividad, pensamos a los deberes como solo la otra cara de la misma moneda en una mera función de instrumentalidad respecto de los derechos. Esa otra cara de la moneda ha terminado al ser la cara "oculta" de la luna, la que nunca se ve. Quizás deba agregarse a este análisis que hay situaciones en las que a la vez puede hablarse de Deber-Derecho, y si tal aclaración es necesaria, sin dudas es porque se las considera autónomas, de lo contrario, si a cada derecho corresponde un deber, sería innecesaria tal caracterización. Por ejemplo el voto en los países en los que es obligatorio se considera un deber-derecho, lo que no sucede en los países en los que es optativo, en los que se lo considera solo un derecho. Es interesante aportar el comentario del Dr. Edgardo Ettlin quien recuerda que la relación entre deberes y derechos debe encontrar un justo medio, es decir, un equilibrio de contrapeso que los ponga en igual, toda vez que las posiciones que se basan en un fuerte acento de unos u otros terminan desnaturalizando al Derecho.

f. Características de los deberes humanos: a partir de su conceptualización, sería interesante poder encontrar algunas características que pueden serles atribuidas y sirvan para ir delineando con un poco de mayor precisión el objeto de estudio.

Universales: los Estados y personas o grupos que estas componen están obligados por igual al cumplimiento de los deberes humanos. Es cierto que si bien esta característica se refiere a deberes negativos parece ser fácilmente atribuible, cuando nos adentramos a los deberes positivos ya se presentan de otra manera, pero la universalidad admite categorías de obligados iguales de acuerdo al deber que se trate, sin excepciones.

Protegen la dignidad humana: la universalidad se conecta indudablemente con la característica de ser protectorios de la dignidad de la persona, la dignidad humana es el bien al que sirven

145 Pedra (2014). 18. 
los deberes humanos y atender a la satisfacción de las necesidades inherentes al desarrollo pleno del ser humano.

De Interpretación Restrictiva: al mandar conductas, la inteligencia del alcance del mandato debe ser entendido de un modo restrictivo, no pudiéndose ampliar el deber a situaciones similares ni por analogía o extensión interpretativa. A su vez nunca un deber debería utilizarse para restringir alterando la naturaleza de derechos humanos.

Indeclinables: los deberes no admiten excusaciones, de ahí la universalidad, todos estamos obligados sin excepción ni renuncias.

Imprescriptibles: el paso de tiempo no afecta la exigibilidad de los deberes, que se mantienen incólumes demandando su satisfacción.

Interdependientes: el cumplimiento de un deber no exime del cumplimiento de otros, a la vez la satisfacción de un deber sin duda promueve como círculo virtuoso el cumplimiento de otros deberes, facilitándolos. Por contrario el incumplimiento de un deber afecta no solo el bien protegido sino desfavorece el cumplimiento de otros deberes.

Irrevocables: no se ha de retroceder, la tarea de visibilización de los mismos es ardua y los deberes reconocidos no admiten su suspensión o eliminación.

g. Destinatarios de los Deberes Humanos: esta cuestión está muy relacionada con el contenido de los deberes. Los deberes humanos son hacia: a. La Comunidad, sea internacional, nacional o local (en este ítem incluimos todas las instancias asociativas de la sociedad, sean gubernamentales o no; b. Otras personas humanas (voy a incluir en este ítem a la familia); c. Uno mismo.

h. Contenido de los deberes humanos. aprovecharé la división realizada en el punto anterior para anotar ciertos contenidos de deberes humanos. Utilizaré para esto una formulación abierta, de alto grado de abstracción que permita luego, en otros trabajos y contextos, un desarrollo de concreción. Asimismo prefiero enumeraciones concisas que las profusamente detalladas. Veamos. 


\section{i. Deberes del Estado}

Deber de respetar los derechos y libertades reconocidos a las personas ${ }^{146}$

Deber de garantizar el goce y ejercicio de derechos y libertades reconocidos a las personas. ${ }^{147}$

Deber de adoptar las medidas legislativas necesarias para garantizar el ejercicio de los derechos. ${ }^{148}$

Deber de investigar y enjuiciar las violaciones a los Derechos Humanos ${ }^{149}$

\section{ii. Deberes de las Personas.}

Deber de participación y respeto de la Comunidad ${ }^{150}$

Deber de convivencia con otros..$^{151}$

Deber de respetar los derechos y libertades de las demás personas $^{152}$

Deberes familiares ${ }^{153}$

Deber de cumplir con la ley y las cargas sociales ${ }^{154}$

Deber de desarrollo personal, cultural y educativo. ${ }^{155}$

Deber de trabajar ${ }^{156}$

\footnotetext{
146 Convención ADH, art. 1.

147 Convención ADH, art. 1.

148 Convención ADH, art. 2.

149 Corte IDH, Velázquez Rodríguez versus Honduras.

150 DUDH, art. 29.1. Pacem in Terris. 31. CAFDHP, art. 27.1

151 DADDH, art. 29. CADH, art. 32.1. Pacem in Terris. 31/34. CAFDHP, art. 27.2-3

152 DADDH, art. 29. Pacem in Terris. 30/34. CAFDHP, art. 27.2-3.

153 DADDH, art. 30. CADH, art. 32.1. CAFDHP, art. 27.1.

154 DADDH, art. 33. CADH, art. 32.1.

155 DADDH, art. 31.

156 DADDH, art. 37. CAFDHP, art. 27.6.
} 
Deber de respetar el ecosistema y las generaciones futuras.

La Declaración de Valencia de 1998 ha detallado un contenido pormenorizado de deberes y obligaciones humanos. Si bien la enumeración es extensa, el hecho que por primera vez se definiera de manera pormenorizada, el contenido de los deberes humanos es un jalón de enorme importancia, por lo que transcribirlos es necesario. Los deberes analizados por la declaración son: El deber y la responsabilidad de la protección de la vida y a lograr la supervivencia tanto de las generaciones actuales como de las futuras. La obligación y responsabilidad de promover la seguridad colectiva y la cultura de la paz. La obligación de promover el desarme en interés de la paz. La obligación de intervenir para impedir graves violaciones de los derechos humanos. La obligación y la responsabilidad de respetar el derecho humanitario internacional en tiempos de conflictos armados. El deber y la responsabilidad de la ayuda humanitaria y la intervención. La obligación y la responsabilidad de proteger y promover un medio ambiente seguro, estable y sano. La obligación y la responsabilidad de promover un orden internacional equitativo. El deber de aliviar la deuda usurera. El deber y la responsabilidad de promover un desarrollo científico y tecnológico seguro, responsable y equitativo. Los deberes y responsabilidades de las corporaciones públicas y del sector privado. El deber y la responsabilidad de impedir y castigar el crimen internacional organizado. La obligación y la responsabilidad de erradicar la corrupción y establecer una sociedad ética. El deber y la responsabilidad de conseguir una participación significativa en los asuntos públicos. La obligación y la responsabilidad de respetar y asegurar la libertad de opinión, de expresión $y$ de los medios de comunicación. Deberes y responsabilidades referentes a las tecnologías de la información y de las comunicaciones. La obligación y la responsabilidad de respetar y asegurar la libertad de reunión y de asociación. El deber y la responsabilidad de respetar y asegurar la libertad de religión, creencias y conciencia. El deber y la responsabilidad de respetar y asegurar la integridad física y personal. El deber y la responsabilidad de respetar y asegurar el derecho a la libertad personal y a la seguridad física. La obligación y la responsabilidad de prohibir e impedir la esclavitud y las instituciones y prácticas análogas a la esclavitud. El deber y la responsabilidad de respetar y asegurar la ausencia de tortura, de tratos o castigos crueles, inhumanos y degradantes. El deber y la responsabilidad de prevenir y erradicar las desapariciones forzosas La obligación de respetar y asegurar un trato igual y la no discriminación El deber y la responsabilidad de respetar y asegurar la igualdad. La obligación y la responsabilidad de asegurar la igualdad racial y religiosa. El deber y la responsabilidad de asegurar la igualdad de sexo y de género. El deber y la responsabilidad de 
asegurar la igualdad de las personas discapacitadas. El deber y la responsabilidad de respetar y proteger los derechos de las minorías. El derecho $y$ la responsabilidad de respetar, proteger y promover los derechos de los pueblos indígenas. La obligación y la responsabilidad de respetar, proteger y promover los derechos de los niños. El deber y la responsabilidad de promover y hacer que se realicen los derechos y el bienestar de los ancianos. El deber y la responsabilidad de promover el derecho a un trabajo justamente remunerado. El deber y la responsabilidad de promover la calidad de vida $y$ un nivel de vida adecuado. El deber y la responsabilidad de promover y aplicar el derecho a la educación. El deber y la responsabilidad de fomentar las artes y la cultura. El deber y la responsabilidad de prever y aplicar recursos efectivos. El deber de observar y poner en práctica la Declaración de Responsabilidades y Deberes Humanos.

\section{CONCLUSIONES}

El objetivo del trabajo ha sido brindar al lector una introducción de los matices más importantes de la cuestión de los deberes humanos

Su comprensión es clave para poder entender la situación actual de las violaciones a la dignidad de las personas que aun hoy día vemos con tan solo informarnos. El diagnóstico es coincidente, a pesar del desarrollo de los derechos humanos la realidad indica que no son respetados. Es que hay situaciones en las que las respuestas del Estado o las asociaciones intermedias no son suficientes, se requiere un cambio de mentalidad por la cual las propias personas, los individuos, participen activamente en la modificación de la realidad y para esto cambiar el paradigma de la supremacía absoluta de los derechos subjetivos con una desconsideración total respecto de los deberes parece una de las posibles soluciones. La expansión de los reclamos de reconocimiento de derechos subjetivos de la posmodernidad produjo una banalización de los derechos, es que si todos son derechos humanos, estos se terminan difuminando al no poder ser reconocidos en su importancia, desapercibidos, quizás como la buscada carta robada de Edgar Allan Poe que no se reconoce entre muchas otras, pese a estar a la vista, al parecer todas iguales. ${ }^{157}$

Delimitar los deberes jurídicos de los morales y los éticos tampoco parece ser tan sencillo, como quizás tampoco lo es ponernos de acuerdo

157 "La Carta Robada", de Edgar Allan Poe (1844). 
en qué es el derecho. Distinguir los deberes humanos de los fundamentales, o constitucionales también parece una tarea a precisar. La noción de deberes positivos y negativos no solo es importante para la ética y el deber de ayuda, es sin dudas una herramienta vital para entender la realización de los derechos económicos, sociales y culturales y su progresividad, así como los deberes emergentes de las cláusulas programáticas.

La invisibilidad de los deberes es un hecho, por cada trabajo sobre deberes hay miles sobre derechos, pero eso es solo un síntoma, lo cierto es que el paradigma del derecho subjetivo explica la situación. No obstante los deberes en cabeza del Estado no parecen estar ocultos, la falta de visibilidad se hace patente en la cuestión de los deberes individuales y es por eso que pongo en titularidad de los deberes humanos a las personas, al individuo que si solo reclama facultades y reconocimientos, nunca asumirá que tiene un papel importante que jugar en la convivencia social, en asumirse dentro de una ética del encuentro con el otro donde el otro, su rostro como explica Levinas, me demanda reconocimiento. Recuerda Felix García Moriyón que "Ante la presencia de otros seres humanos, nos sentimos interpelados por su dignidad inalienable, descubrimos al mismo tiempo el derecho a que me respeten y el deber de respetarlos, ambos inseparables hasta el punto que olvidar uno de ellos supone inmediatamente la imposibilidad de construir una sociedad solidaria, pasando a malvivir con unas relaciones de dominación y explotación”. ${ }^{158}$ Quizás esta mirada ética pueda ayudarnos a recuperar la centralidad que los deberes tienen que recuperar.

La invisibilidad de los deberes alcanza una especial profundidad en cuanto a los deberes que corresponden a las personas individuales. Respecto de los deberes estatales existe un desarrollo vinculado a los derechos de segunda generación que les impone al Estado fuertes deberes de cumplimiento positivo.

Las caracterizaciones de los Deberes Humanos son una propuesta, su concepto, características, clasificaciones las he realizado a fin de esbozar su idea, y como todo boceto, debe precisar.

En 2018 se cumplirán aniversarios, tanto de la DUDH, como de la DV, será imperioso recuperar el diálogo sobre los deberes, para discutirlos, para hacer visibles, pero sobre todo para asumirlos, al fin y al

158 García Moriyón (1998). 95. 
cabo, el incorporarlos a las declaraciones no es más que un paso hacia un fin, el respeto universal de la dignidad del hombre a partir de una decisión personal que quizás, como los propios deberes humanos, sea una tarea pendiente.

\section{REFERENCIAS BIBLIOGRÁFICAS}

Aristóteles (2007). Política. Alianza Editorial. Buenos Aires.

Bandieri, L. (2011) Derechos Fundamentales ¿̇Y Deberes Fundamentales? en Direitos, Deveres e Garantias Fundamentais, Editora JusPodium, Salvador, consultado en https://www.academia.edu/9075725/_ Derechos_fudamentales_y_deberes_fundamentales_

Bayón, J. (1986). Los deberes positivos Generales y la determinación de sus límites (observaciones al artículo de Ernesto Garzón Valdes), Rev. Doxa - 1986, $\mathrm{n}^{\circ} 3$, consultado en http://rua.ua.es/dspace/handle/10045/10965

Busch Venthur, T. (2012). Deberes Constitucionales, en Anuario de Filosofía Jurídica y Social, $n^{\circ}$ 30, Ponencias en Valparaíso II, Sociedad Chilena de Filosofía Jurídica y Social. Consultado en: http://filosofiajuridica.cl/wp-content/uploads/2015/02/2012-3-busch.pdf

Carbonell, M. (2009). El momento fundacional de los Derechos. Notas sobre la Declaración de los Derechos del Hombre y del Ciudadano de 1789, consultado en https://aprendeenlinea.udea.edu.co/revistas/index. php/red/article/viewFile/5206/4532

Cicerón, M. (2001). Sobre los deberes. Alianza Editorial SA, Madrid.

Colomer Segura, A. (2012). Una aproximación a los deberes positivos desde la Doctrina del Buen Samaritano, Cuadernos Electrónicos de Filosofía del Derecho; No 26; 42-56. Universitat de Valencia, en http:// ojs.uv.es/index.php/CEFD/article/view/1844

Contreras Pelaez, F. y Perez Luño, A. (2009). Michel Villey y España, Rev. Droit et Société, $n^{\circ} 71$. 47-68. Consultado en https://es.scribd. com/doc/149520863/villey 
Daros, W. (2013). La invisibilización de los Deberes Humanos Universales. Enfoques. 2013, XXV, $\mathrm{n}^{\circ} 2$, consultado en https://williamdaros. files.wordpress.com/2009/08/la-invisibilizacic3b3n-de-los-deberes-humanos-huniversales.pdf

Díaz Revorio, F. (2011). Derechos Humanos y Deberes Fundamentales. Sobre el concepto de deber constitucional y los deberes en la Constitución Española de 1978. Re. IUS, Instituto de Ciencias Jurídicas de Puebla, México, Año V, núm. 28, julio-diciembre de 2011.

Escobar Rozas, F. (1999). Algunas cuestiones fundamentales sobre el deber jurídico. Revista de la Facultad de Derecho, n ${ }^{\circ}$ 52, PUCP, consultado en: http://revistas.pucp.edu.pe/index.php/derechopucp/article/view/6406

Ettlin, E. (2013). Una Teoría General sobre los Deberes Humanos. https://www.academia.edu/7410958/LOS_DEBERES_HUMANOS?auto $=$ download

Fernández, E. (1984). Teoría de la justicia y derechos humanos. Editorial Debate. Madrid, 1984. 79. Referenciado en "Por qué tenemos Derechos Humanos", Antonieta Reyes Prado consultado en http://www. corteidh.or.cr/tablas/R22848.pdf

Foucault, M. (2003). La verdad y las formas jurídicas, Ed. Gedisa, Barcelona.

García Moriyón, F. (1998) Los derechos humanos a lo claro. Editorial Popular, en http://www.amnistiacatalunya.org/edu/2/dh/dh-der-deberes-moriyon.html

Garzón Valdés, E (1986). Los Deberes Positivos Generales y su fundamentación, Rev. Doxa - 1986, n 3, consultado en http://rua.ua.es/ dspace/handle/10045/10965

Goldschmidt, W. (1978). Introducción Filosófica al Derecho. La Teoría Trialista del Mundo Jurídico y sus horizontes. $6^{\circ}$ Edición, Depalma, Buenos Aires.

González Faus, J. (2002) ¿Por qué fallan las revoluciones?, en diario "La Vanguardia" del 27-2-02, editado en Barcelona, consultado en 
http://www.amnistiacatalunya.org/edu/2/dh/dh-der-deberes-gonzalezfaus.html

Juan XXIII (1963). Pacem in Terris, consultado en http://w2.vatican.va/content/john-xxiii/es/encyclicals/documents/hf_j-xxiii_ enc_11041963_pacem.html\#_ftnref7

Kelsen, H. (2009). Teoría Pura del Derecho, Ed. Eudeba, Buenos Aires.

Lipovetsky, G. (1994). El crepúsculo del deber (La ética indolora de los nuevos tiempos democráticos). Ed. Anagrama, Barcelona.

Maino, C. (2011). Derechos fundamentales y la necesidad de recuperar los deberes, en Direitos, deveres e garantías fundamentais, Coords. George S. Leite, Ingo W. Sarlet y Miguel Carbonell, Ed. Jus Podium, Salvador de Bahía.

Massini Correas, C. (2005). Filosofía del Derecho, t. 1, Ed. Nexis Lexis Argentina, Buenos Aires.

Massini Correas, C. (2010). Derechos Humanos y bienes humanos. Consideraciones preciso-valorativas a partir de las ideas de John Finnis. Rev. Metafísica y Persona. Filosofía, conocimiento y vida. Año 2, Enero-Junio 2010, núm. 3. Univ. De Málaga - UPAEP. Consultado en http:// metyper.com/wp-content/uploads/2014/12/MYP_R3_A7_WEB.pdf

Moisset de Espanés, L. (1966). Los deberes morales y las obligaciones naturales. Cuaderno del Instituto de Derecho Civil de Córdoba, ${ }^{\circ}$ 99, consultado en http://www.acaderc.org.ar/doctrina/articulos/los-deberes-morales-y-las-obligaciones-naturales

Oraá, J. (1998). Artículo 29. Los deberes en la Declaración Universal de Derechos Humanos, en La Declaración Universal de los Derechos Humanos, Comentario artículo por artículo, Asociación para las Naciones Unidas en España, Editorial Icaria, Barcelona.

Oraá, J. (2004). La Declaración Universal de Derechos Humanos, en La protección internacional de los derechos humanos en los albores del siglo XXI, Universidad de Deusto Bilbao, consultado en http://www. corteidh.or.cr/tablas/27570.pdf 
Palombella, G. (2007). De los derechos y su relación con los deberes y los fines comunes, en Rev. Derechos y Libertades núm. 17, Época II, junio 2007, Universidad de Parma.

Pedra, A. (2014). Los Deberes de las Personas y la realización de los Derechos Fundamentales, en Rev. Estudios Constitucionales, año 12, núm. 2, Universidad de Talca.

Peces-Barba, G. (1987). Los deberes Fundamentales. Rev. Doxa $n^{\circ} 4$ 1987, consultadoenhttps://rua.ua.es/dspace/bitstream/10045/10915/1/ Doxa4_19.pdf

Recaséns Siches, L. (2000). Vida Humana, Sociedad y Derecho. Fundamentación de la Filosofía del Derecho, Biblioteca virtual Miguel de Cervantes, Alicante; consultado en http://www.cervantesvirtual.com/ obra/vida-humana-sociedad-y-derecho-fundamentacion-de-la-filosofia-del-derecho--0/

Revault D'Allonnes, M. (2010). Lo que el hombre hace al hombre. Ensayo sobre el mal político. Amorrortu editores, Buenos Aires.

Spector, H. (2001). La filosofía de los Derechos Humanos. Rev. Isonomia, núm. 15.

Sófocles (2001). Antígona. Pehuén Editores. Consultado en http:// assets.una.edu.ar/files/file/artes-dramaticas/2016/2016-ad-una-cino-antigona-sofocles.pdf

Weil, S. (2000). Raíces del Existir. Editorial Sudamericana, Buenos Aires.

\section{Documentos}

CADH - PSJCR. Convención Americana de Derechos Humanos Pacto de San José de Costa Rica. (1969)

CAFDHP - Carta Africana sobre los Derechos Humanos y de los Pueblos - Carta de Banjul. (1981)

CC OEA. Carta Constitutiva de la Organización de Estados Americanos. (1948) 
CC ONU. Carta Constitutiva de la Organización de las Naciones Unidas. (1945)

CDFUE - Carta de los Derechos Fundamentales de la Unión Europea. (2007).

DADDH. Declaración Americana de los Derechos y Deberes del Hombre. (1948)

DDRH - DV. Declaración de Deberes y Responsabilidades del Hombre - Declaración de Valencia. (1998)

DUDH. Declaración Universal de Derechos Humanos (1948)

Recibido: 20/12/2017

Aceptado: 24/05/2018

Dr. Emilio Germán Ardiani Alvariza, Mgtr.: Profesor de Derecho Constitucional y Ética Profesional, UCEL (Argentina).

Correo electrónico: emilioardiani@gmail.com 